\title{
Biphasic Opening of the Blood-Brain Barrier Following Transient Focal Ischemia: Effects of Hypothermia
}

\author{
Z. Gao Huang, Dong Xue, Edward Preston, Hasneen Karbalai, \\ Alastair M. Buchan
}

\begin{abstract}
Objective: Tracer constants $\left(\mathrm{K}_{\mathrm{i}}\right)$ for blood-to-brain diffusion of sucrose were measured in the rat to profile the time course of blood-brain barrier injury after temporary focal ischemia, and to determine the influence of post-ischemic hypothermia. Methods: Spontaneously hypertensive rats were subjected to transient ( 2 hours) clip occlusion of the right middle cerebral artery. Reperfusion times ranged from $1.5 \mathrm{~min}$ to 46 hours, and i.v. ${ }^{3} \mathrm{H}$-sucrose was circulated for $30 \mathrm{~min}$ prior to each time point (1h, $4 \mathrm{~h}$, $22 \mathrm{~h}$, and $46 \mathrm{~h} ; \mathrm{n}=5-7$ per time point). $\mathrm{K}_{\mathrm{i}}$ was calculated from the ratio of parenchymal tracer uptake and the time-integrated plasma concentration. Additional groups of rats $(\mathrm{n}=7-8)$ were maintained either normothermic $\left(37.5^{\circ} \mathrm{C}\right)$ or hypothermic $\left(32.5^{\circ} \mathrm{C}\right.$ or $\left.28.5^{\circ} \mathrm{C}\right)$ for the first 6 hours of reperfusion, and $\mathrm{K}_{\mathrm{i}}$ was measured at 46 hours. Results: Rats injected after 1.5 - 2 min exhibited a 10-fold increase in $\mathrm{K}_{\mathrm{i}}$ for cortical regions supplied by the right middle cerebral artery $(\mathrm{p}<0.01)$. This barrier opening had closed within 1 to 4 hours postreperfusion. By 22 hours, the blood-brain barrier had re-opened, with further opening 22 and 46 hours ( $<<0.01)$, resulting in edema. Whole body hypothermia $\left(28^{\circ} \mathrm{C}-29^{\circ} \mathrm{C}\right)$ during the first six hours of reperfusion prevented opening, reducing $\mathrm{K}_{\mathrm{i}}$ by over $50 \%$ ( $<<0.05$ ). Conclusions: Transient middle cerebral artery occlusion evokes a marked biphasic opening of the cortical blood-brain barrier, the second phase of which causes vasogenic edema. Hypothermic treatment reduced infarct volume and the late opening of the blood-brain barrier. This opening of the blood-brain barrier may enhance delivery of low permeability neuroprotective agents.
\end{abstract}

RÉSUMÉ: Ouverture biphasique de la barrière hémato-encéphalique suite à une ischémie focale transitoire: effets de l'hypothermie. Objectif: Nous avons mesuré les constantes d'un traceur $\left(\mathrm{K}_{\mathrm{i}}\right)$ de la diffusion de sucrose du sang vers le cerveau chez le rat afin d'observer l'évolution des dommages subis par la barrière hémato-encéphalique après une ischémie focale temporaire et pour déterminer les effets d'une hypothermie postischémique. Méthodes: Des rats spontanément hypertendus ont été soumis à une occlusion de deux heures de l'artère cérébrale moyenne par un clip. Le temps de reperfusion variait de 1.5 minute à 46 heures et une perfusion intraveineuse de ${ }^{3} \mathrm{H}$-sucrose a été administrée pendant 30 minutes avant chaque évaluation ponctuelle ( $1 \mathrm{~h}, 4 \mathrm{~h}, 22 \mathrm{~h}$, et $46 \mathrm{~h} ; \mathrm{n}=5-7$ par évaluation ponctuelle). La constante $\mathrm{K}_{\mathrm{i}}$ a été calculée à partir de l'indice de captation du traceur par le parenchyme et de la concentration plasmatique en fonction du temps. Des groupes additionnels de rats $(\mathrm{n}=7-8)$ ont été maintenus soit à la température normale $\left(37.5^{\circ} \mathrm{C}\right)$ ou en hypothermie $\left(32.5^{\circ} \mathrm{C}\right.$ ou $\left.28.5^{\circ} \mathrm{C}\right)$ pendant les 6 premières heures de la reperfusion et $\mathrm{K}_{\mathrm{i}}$ a été mesurée à 46 heures. Results: Les rats qui ont reçu l'injection après 1.5 - 2 minutes présentaient une augmentation de $\mathrm{K}_{\mathrm{i}}$ de dix fois supérieure dans les régions corticales irriguées par l'artère cérébrale moyenne $(\mathrm{p}<0.01)$. Cette ouverture de la barrière s'était refermée 1 à 4 heures post-reperfusion. À 22 heures, la barrière hémato-encéphalique s'était réouverte, davantage à 22 et à 46 heures $(\mathrm{p}<0.01)$, ce qui a donné lieu à de l'œdème. L'hypothermie généralisée $\left(28^{\circ} \mathrm{C}\right.$ $29^{\circ} \mathrm{C}$ ) pendant les 6 premières heures de la reperfusion a empêché son ouverture, diminuant ainsi la constante $\mathrm{K}_{\mathrm{i}}$ de plus de $50 \%$ ( $\mathrm{p}<0.05$ ). Conclusions: L'occlusion transitoire de l'artère cérébrale moyenne provoque une ouverture biphasique importante de la barrière hémato-encéphalique corticale dont la deuxième phase cause de l'œdème. L'hypothermie a diminué la taille de l'infarctus cérébral et l'ouverture tardive de la barrière hémato-encéphalique. Cette ouverture de la barrière hémato-encéphalique peut accroître la distribution d'agents neuroprotecteurs à basse perméabilité.

Can. J. Neurol. Sci. 1999; 26: 298-304

Brain capillary walls are distinguished by an endothelial cell layer replete with tight junctions and a scarcity of fenestrae. This blood-brain barrier (BBB) is a specialization which maintains homeostasis of the neuronal micro-environment, limiting bloodto-brain diffusion of hydrophilic molecules. Penetration is largely restricted to lipophilic substances capable of directly traversing endothelial membranes, and to hydrophilic substances such as amino acids and glucose, for which specific membrane carriers exist. ${ }^{1,2}$ BBB drainage, following brain ischemia, leads to the extravascular leakage of plasma proteins and other solutes, resulting in an imbalance with osmotic forces drawing excess water into the tissue (i.e. vasogenic edema). ${ }^{3}$ Tissue swelling ensues within the rigid confines of the skull, elevating intracranial pressure with secondary ischemia due to compression of microvasculature, and, ultimately, brain herniation. ${ }^{4}$

From the Alberta Stroke Program, Department of Clinical Neurosciences, University of Calgary, Alberta, (ZGH ,DX, HK, AMB); and the Institute for Biological Sciences, National Research Council, Ottawa, Ontario, Canada (ZGH, DX, EP) RECEIVED JANUARY 9, 1999. ACCEPTED IN FINAL FORM MAY 18, 1999 Reprint requests to: Alastair M. Buchan, Alberta Stroke Program, Office of Stroke Research, Room 1162, Foothills Hospital, 1403 - 29th Street NW, Calgary, AB, Canada T2N 2T9 
A reproducible rodent model used to study focal brain ischemia involves temporary (e.g. 0.5 to 4 hours, or permanent occlusion of a middle cerebral artery [MCAO model] with tandem occlusion of the ipsilateral common carotid artery). 5,6,7 Temporary MCAO enables the study of both positive and negative aspects of post-ischemic reperfusion, which occurs clinically, both spontaneously and therapeutically, with the advent of r-tPA, newly licensed as a thrombolytic agent for ischemic stroke in the first three hours. Restoration of blood flow, if early enough, may offer the advantage of reducing neuronal damage and limiting infarct extension and enhances potentially cytoprotective drug delivery. These benefits may be undermined by reperfusion injury to the microvasculature, compromising BBB function, exacerbating edema formation and the inflammatory developments that follow. ${ }^{2,3,4}$ Dynamic changes in BBB permeability, which follow temporary MCAO, are therefore of critical importance.

The objective of this study was to delineate the time course and intensity of the $\mathrm{BBB}$ opening after reversible $\mathrm{MCAO}$ ischemia in the rat using a method involving a removable, atraumatic clip. ${ }^{6}$ Post ischemic changes in the BBB were studied using a modification ${ }^{8}$ of a radiotracer methodology, which quantifies even minor degrees of $\mathrm{BBB}$ opening with a high degree of sensitivity. ${ }^{9,10}$ The radiotracer method used in this study is based on a 2-compartment (plasma/brain) simple diffusion model, which assumes that the amount of ${ }^{3} \mathrm{H}$-sucrose, which permeates the microvasculature into brain parenchyma, does so in proportion to the time integral of plasma tracer concentration. Normal BBB permeability and opening are indexed in the ratio of parenchymal uptake relative to plasma integral, calculated as the transfer constant, $\mathrm{K}_{\mathrm{i}}{ }^{9,10}$ The effects of delayed hypothermia ${ }^{11}$ on the biphasic $\mathrm{BBB}$ opening were also investigated.

\section{Methods ANd Materials}

Male spontaneously hypertensive rats (SHR) weighing $170 \mathrm{~g}$ $-225 \mathrm{~g}$ were fasted for 18 hours prior to surgery, but allowed free access to water. Animals were initially anesthetized with $3 \%$ halothane, and subsequently maintained on $1-2 \%$ halothane mixed with $70 \%$ nitrogen and $28 \%$ oxygen. Body temperature was maintained at $37.5^{\circ} \mathrm{C} \pm 0.5^{\circ} \mathrm{C}$ during surgery, by rectal thermistor coupled to a heating lamp.

The method for producing reversible focal ischemia has been fully described. ${ }^{6}$ The right common carotid artery was isolated through a ventral midline neck incision and ligated. A $1 \mathrm{~cm}$ incision was made perpendicular to and bisecting a line between the lateral canthus and the right eye and the external auditory canal. The underlying temporalis muscle was partially excised. A burr hole, $1 \mathrm{~mm}$ in diameter, was drilled $2-3 \mathrm{~mm}$ rostral to the point of fusion of the zygomatic arch with the temporal bone. Drilling was accompanied by a gentle drip of isotonic saline to prevent warming of the underlying cortex. The dura over the MCA was then cut and retracted. A \#1 micro-clip (Codman) was placed on the MCA at a site proximal to the point where it crosses the inferior cerebral vein in the rhinal fissure. The incisions were then closed with wound clips.

Animals were subjected to two hours of ischemia, during which time the anesthesia was discontinued and the animals allowed to regain consciousness. At the end of ischemia, the rats were briefly re-anesthetized with halothane, the MCA clip removed, and blood re-flow through the MCA visually verified. The wound was sutured closed, and the animal permitted to regain consciousness. Sham groups of animals were treated in the same manner, except the micro-clip was placed on the MCA and then removed immediately. Animals were maintained at a rectal temperature of $37^{\circ} \mathrm{C}-38^{\circ} \mathrm{C}$ for all procedures, except where indicated otherwise in the hypothermic experiments.

Regional transfer constants $\left(\mathrm{K}_{\mathrm{i}}\right)$ for BBB permeation of ${ }^{3} \mathrm{H}$ sucrose were measured by a previously published method. ${ }^{8,10}$ modified after 9 Measurements were made at different time points after reperfusion of the right MCA. The rats were anesthetized with pentobarbital (65 mg/kg i.p.) and, after cannulation of a femoral artery and vein, ${ }^{3} \mathrm{H}$-sucrose (NET-341) was injected intravenously $(20 \mu \mathrm{Ci} / 100 \mathrm{~g}$, in $0.5 \mathrm{ml}$ saline $)$. Immediately upon tracer injection, syringe-pump sampling of femoral arterial blood was begun at a constant rate $\left(0.039 \mathrm{ml} / \mathrm{min}^{-1}\right)$ and continued for $30 \mathrm{~min}$. At this point, sampling was stopped and the brain was immediately cleared of intravascular $\operatorname{tracer}^{8}$ by perfusing $25 \mathrm{ml}$ saline at $100-130 \mathrm{~mm} \mathrm{Hg}$ pressure through a cannula inserted a few minutes beforehand into the right carotid artery. ${ }^{12}$ The rat was decapitated, the brain removed and dissected bilaterally into the cortex (about $180 \mathrm{~mm}^{3}$, representing the complete MCA supply territory), striatum, and hippocampus. Brain samples (weighed) and measured volumes of plasma from the arterial sample were placed in the scintillation vials and solubilized overnight at $37.5^{\circ} \mathrm{C}$ in $1.3 \mathrm{ml}$ Soluene 350 (Packard Instr.). $10 \mathrm{ml}$ of fluor (HionicFluor) was added to all vials and the samples were counted by liquid scintillation to determine the tracer level in the brain parenchyma $\left(\mathrm{C}_{\mathrm{paren}}, \mathrm{dpm} \cdot \mathrm{g}^{-1}\right)$ and the time integral of the plasma tracer level $\left(\alpha^{1800} \mathrm{C}_{\text {plasma }} \mathrm{dt}\right.$, dpm.s.ml $\left.{ }^{-1}\right)$. The integral was obtained by multiplying the plasma concentration $\left(\mathrm{C}_{\text {plasma, }}\right.$ dpm. $\mathrm{ml}^{-1}$ ) by the circulation time (1800s). The transfer constant $\left(\mathrm{K}_{\mathrm{i}}, \mathrm{mL} \cdot \mathrm{g}^{-1} \cdot \mathrm{s}^{-1}\right)$ was calculated from the relationship: $\mathrm{K}_{\mathrm{i}}=$ $\mathrm{C}_{\text {paren }} / \alpha^{1800} \mathrm{C}_{\text {plasma }} \mathrm{dt}^{9}{ }^{9}$

In Experiment 1, radiotracer studies were carried out at 1, 4, 22, and 46 hours after reperfusion (or 3, 6, 24, and 48 hours after the onset of ischemia) with five animals in each group. In an additional group $(n=5)$, the radiotracer experiments were initiated within $1.5-2$ min after reperfusion. In this case only, pentobarbital rather than halothane, anesthesia was induced 15 min before reperfusion for cannulations and clip removal. A group of sham-operated rats ( $\mathrm{n}=7$ total) was studied at $1,2,3$, 5 , and 24 hours after sham occlusion, with one or two rats at each time point. No sham-operated rats were studied at 1.5 - 2 minutes.

In Experiment 2, rats underwent mild or moderate hypothermia during the first 6 hours of reperfusion. Ten minutes before the end of 2 hours of MCA occlusion, the rats were lightly halothane anesthetized and were surrounded by bags of crushed ice. This caused body temperature to drop to $32^{\circ} \mathrm{C}-33^{\circ} \mathrm{C}$ at the time that the MCA clip was removed. Rectal temperature was maintained for 6 hours at $32^{\circ} \mathrm{C}-33^{\circ} \mathrm{C}$ for the mild hypothermic group $(\mathrm{n}=7)$ or $28^{\circ} \mathrm{C}-29^{\circ} \mathrm{C}$ for the moderate hypothermic group $(n=7)$. Control animals, maintained at $37^{\circ} \mathrm{C}-38^{\circ} \mathrm{C}$, were concurrently studied with their hypothermic peers, such that two normothermic groups were formed $(n=8$ for the mild hypothermia controls, and $n=7$ for the moderate hypothermia controls). During the six hours, halothane was continued at $0.5-$ $0.7 \%$ for the hypothermia groups only, as the control group did 
Table 1: Regional Transfer Constant $\left(\mathrm{K}_{\mathrm{i}}\right)$ in MCA Model (Experiment 1)

\begin{tabular}{|c|c|c|c|c|c|c|}
\hline Sham (7) & $1.6 \pm 0.8^{b}$ & $1.3 \pm 0.6^{\mathrm{b}}$ & $1.7 \pm 0.7$ & $1.9 \pm 0.4$ & $1.3 \pm 0.3$ & $1.9 \pm 0.3$ \\
\hline RP-1 Hour (5) & $5.7 \pm 4.1^{\mathrm{ac}}$ & $2.4 \pm 1.0$ & $2.3 \pm 0.9$ & $2.3 \pm 0.4^{\mathrm{d}}$ & $1.9 \pm 0.8$ & $2.1 \pm 0.4$ \\
\hline RP-4 Hours (5) & $5.9 \pm 2.9^{\mathrm{ab}}$ & $2.7 \pm 1.9$ & $2.0 \pm 1.0$ & $3.0 \pm 1.4$ & $2.1 \pm 1.1$ & $2.7 \pm 1.1$ \\
\hline RP-22 Hours (5) & $13.1 \pm 2.0^{\mathrm{abc}}$ & $5.3 \pm 1.0^{\mathrm{ab}}$ & $2.4 \pm 0.5^{b}$ & $2.3 \pm 0.7^{\mathrm{d}}$ & $1.6 \pm 0.4^{\mathrm{d}}$ & $2.3 \pm 0.9$ \\
\hline RP-46 Hours(5) & $59.0 \pm 9.3^{\mathrm{ac}}$ & $16.5 \pm 6.8^{\mathrm{a}}$ & $6.0 \pm 2.6^{\mathrm{a}}$ & $2.5 \pm 0.8^{\mathrm{d}}$ & $2.1 \pm 0.78^{d}$ & $2.7 \pm 0.8$ \\
\hline
\end{tabular}

$\mathrm{p}<0.05$ for ANOVA plus Tukey's test.

Within tissues and between treatments: $a$ - different from control (sham stroke) value; $b$ - different from value immediately below.

Within treatments and between tissues: $\mathrm{c}$ - different from all other values; $\mathrm{d}$ - left side values different from corresponding right side values.

not require anesthesia during reperfusion. Afterwards, these animals were permitted to recover from anesthesia and return to normothermic conditions. Radiotracer experiments were carried out at 46 hours post-reperfusion.

In Experiment 3, to assess edema development after two hours of MCA occlusion, rats were sacrificed by decapitation after 4 (n $=5)$, and $46(n=6)$ hours of reperfusion. Samples of right and left cortex were dissected out and the percentage water content was obtained by weight difference after complete oven drying. The effect of 6 hours post-reperfusion hypothermia was also examined in relation to edema formation. Six rats were subjected to 6 hours of post-reperfusion moderate hypothermia $\left(28^{\circ} \mathrm{C}-29^{\circ} \mathrm{C}\right)$ followed by 40 hours of normothermia $\left(37^{\circ} \mathrm{C}-38^{\circ} \mathrm{C}\right)$.

In Experiment 4, neocortical infarct volume was measured in separate animals to determine the effect of hypothermia after MCAO. Rats underwent two hours of ischemia and were then kept either normothermic $(n=6)$, or immediately underwent 6 hours of mild $\left(32^{\circ} \mathrm{C}-33^{\circ} \mathrm{C}, \mathrm{n}=6\right)$ or moderate $\left(28^{\circ} \mathrm{C}-29^{\circ} \mathrm{C}, \mathrm{n}\right.$ = 6) hypothermia, as above. Rats were anesthetized and decapitated after 46 hours of reperfusion and the brains removed and frozen. Coronal sections, $20 \mu \mathrm{m}$ thick, were cut at $-25^{\circ} \mathrm{C}$, and every 25 th section was saved. The sections were stained with hematoxylin and eosin, and infarct volume and edema were obtained with an image processing system (Image-Pro II). Infarct area of each section was traced, and the total infarct volume was calculated by summing the infarcted area of sequential sections and multiplying the interval thickness between sections. Edema was calculated by comparing the increase in size of the right hemisphere as compared to the left hemisphere.

Statistical analyses used in the transfer constant and edema studies were the ANOVA plus Tukey's test. A two-tailed Student's t test was used to compare cortical infarct volumes in hypothermic versus control animals. A p-value of less than 0.05 was taken to indicate statistical significance. All values are presented as $\pm \mathrm{SD}$.

\section{RESULTS}

\section{Experiment 1}

Mean regional transfer constants for the six groups of normothermic rats are summarized in Table 1. In 7 sham-stroked rats, radiotracer measurements were initiated at 1, 2, 3, 5, or 24 hours after the sham procedure. Each time period group contained 1 animal, except for the 3 and 24 hour groups, which contained 2 animals each. There were no significant differences between the regional $\mathrm{K}_{\mathrm{i}}$ values for cerebral tissues on the right side of the brain (which had undergone a complete surgical procedure, except for MCA occlusion), and those of corresponding territories on the left side. In the 5 experimental groups of rats which underwent 2 hours of MCA occlusion (each group: $\mathrm{n}=5$ ), the largest blood-brain barrier openings and increases in $\mathrm{K}_{\mathrm{i}}$ took place in the right neocortical tissue supplied by the occluded right MCA (Table 1). When the 30 min tracer circulation period began $1.5-2$ min after reperfusion, there was evidence of an early increase in mean $\mathrm{K}_{\mathrm{i}}$ to greater than 10 -fold of the baseline value. This was followed by a partial recovery, with subsequent $\mathrm{K}_{\mathrm{i}}$ measurements and 1 and 4 hours postreperfusion, which were significantly lower than the acute (1.5 2 min) group values, although still elevated above baseline and above values for the contralateral, non-ischemic side. A late opening in the BBB was then demonstrated 4 and 22 hours postreperfusion. This was most pronounced between 22 and 46 hours (Figure 1).

Striatum removed from the right hemisphere of stroked rats exhibited a slight but significant elevation in $\mathrm{K}_{\mathrm{i}}, 1.3-2$ min postreperfusion (Table 1). This change was no longer present at 1 or 4 hours post-reperfusion, however, a significant increase in $\mathrm{K}_{\mathrm{i}}$ was demonstrated between 22 and 46 hours after reperfusion. The dorsal hippocampus ipsilateral to the MCA occlusion showed little change in $\mathrm{K}_{\mathrm{i}}$, except at the 46 hour time point, when a slight elevation was present. In the contralateral, non-ischemic 


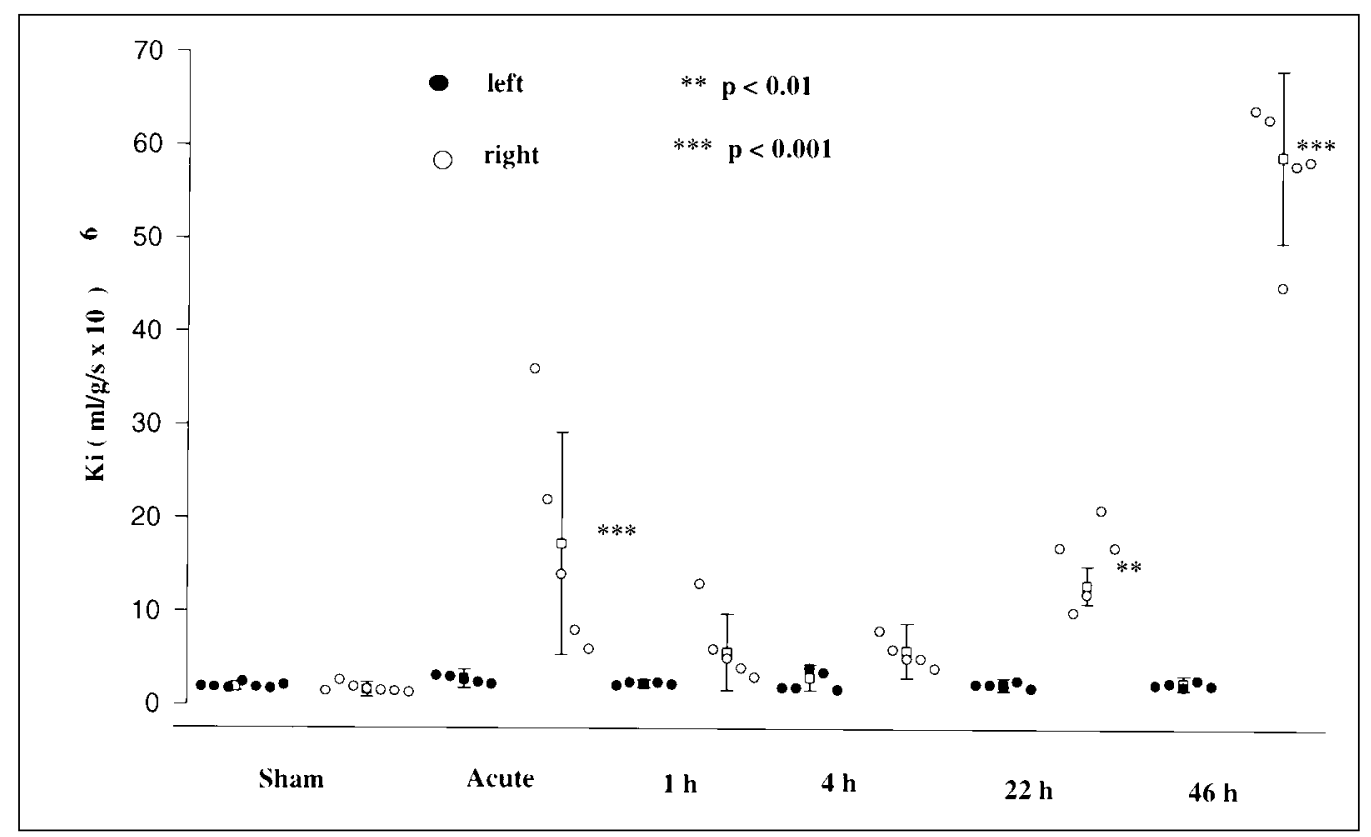

Figure 1: Biphasic opening of the blood-brain barrier in right cerebral cortex of the rat after 2 hours of occlusion and 46 hours of reperfusion of the right MCA. Opening of BBB indicated by increased transfer constant $K_{i}$ for blood-to-brain diffusion of ${ }^{3} H$-sucrose. The $K_{i}$ values for the right cortex (ipsilateral to the MCA occlusion) and left cortex from individual animals are represented by open and shaded circles, respectively. The open square with error bars represent the mean $\pm S D$ for each time period. $* * p<0.01$; *** $p<0.001$, significantly elevated from control values.

hemisphere, all regions exhibited mean $\mathrm{K}_{\mathrm{i}}$ values slightly higher then the baseline, sham stroke values. However, in no instance was this statistically significant.

\section{Experiment 2}

Table 2 shows the effect of mild or moderate hypothermia for 6 hours post-reperfusion on BBB opening caused by MCAO. Mean $\mathrm{K}_{\mathrm{i}}$ measured 46 hours post-reperfusion was lower in rats that underwent hypothermia $\left(32^{\circ} \mathrm{C}-33^{\circ} \mathrm{C}\right)$ compared to that of normothermic controls. With moderate hypothermia of $28^{\circ} \mathrm{C}$ $29^{\circ} \mathrm{C}$, the reduction in $\mathrm{BBB}$ opening was more striking.

\section{Experiment 3}

Table 3 reports edema measurements based on the wet to dry weight difference as a percentage of water per cerebral hemisphere $\left(\mathrm{ml}^{-\mathrm{g}^{-1}} \mathrm{x} 100\right)$. In 5 rats sacrificed 4 hours postreperfusion, the values (mean $\pm \mathrm{SD}$ ) were $80.4 \pm 0.3 \%$ and 78.5 $\pm 0.2 \%$ for the right and left sides, respectively $(\mathrm{p}<0.001)$. Furthermore, the mean $\% \mathrm{H}_{2} \mathrm{O}$ measured in the stroked hemisphere at 22 hours post-reperfusion was significantly higher than that at 4 hours $(\mathrm{p}<0.01)$, whereas, in the non-ischemic hemisphere there was no significant difference between these two time points.

Table 2: Effect of Mild and Moderate Post-Ischemic Hypothermia on Transfer Constant $\left(\mathrm{K}_{\mathrm{i}}\right)$ (Experiment 2)

\begin{tabular}{|c|c|c|c|c|c|c|}
\hline $\begin{array}{l}\text { Variability } \\
\text { Group (n) }\end{array}$ & \multicolumn{3}{|c|}{$\begin{array}{c}\text { Right } \\
\left(\text { Mean } \pm \text { SD) }\left(\mathrm{mL} \cdot \mathrm{g}^{-1} \cdot \mathrm{s}^{-1} \times \mathbf{1 0}^{6}\right)\right.\end{array}$} & \multicolumn{3}{|c|}{ 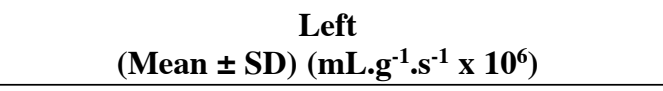 } \\
\hline Normothermia (8) & $30.6 \pm 9.1$ & $5.2 \pm 3.0$ & $2.0 \pm 0.5$ & $1.2 \pm 0.2$ & $1.1 \pm 0.3$ & $1.5 \pm 0.3$ \\
\hline Normothermia (7) & $34.7 \pm 10.9$ & $5.0 \pm 1.3$ & $2.7 \pm 1.2$ & $2.0 \pm 0.4$ & $1.0 \pm 1.0$ & $2.3 \pm 1.0$ \\
\hline $\begin{array}{l}\text { Hypothermia (7) } \\
28-29^{\circ} \mathrm{C}\end{array}$ & $15.4 \pm 8.8^{* *}$ & $3.7 \pm 1.7$ & $1.8 \pm 0.7$ & $1.5 \pm 0.2$ & $1.2 \pm 0.3$ & $1.8 \pm 0.4$ \\
\hline
\end{tabular}


Table 3: Percentage of Water in MCA Model (Experiment 3)

\begin{tabular}{|c|c|c|}
\hline Variability & $\begin{array}{c}\text { Right Cortex } \\
\% \text { of Water }(\text { Mean } \pm \text { SD) }\end{array}$ & $\begin{array}{c}\text { Left Cortex } \\
\% \text { of Water }(\text { Mean } \pm \text { SD) }\end{array}$ \\
\hline \multicolumn{3}{|l|}{ Normothermia } \\
\hline 4 hours post-reperfusion (5) & $80.4 \pm 0.3^{\mathrm{a}}$ & $78.5 \pm 0.2$ \\
\hline 22 hours post-reperfusion (5) & $83.7 \pm 0.6^{\mathrm{ab}}$ & $78.8 \pm 0.1$ \\
\hline 46 hours post-reperfusion (6) & $86.1 \pm 0.7^{\mathrm{ab}}$ & $79.8 \pm 0.7$ \\
\hline $\begin{array}{l}\mathrm{p}<0.01 \text { for ANOVA } \\
\mathrm{a}-\text { right side values }\end{array}$ & nding left side values; $b$ - differ & t-reperfusion value. \\
\hline
\end{tabular}

Post-ischemic hypothermia $\left(28^{\circ} \mathrm{C}-29^{\circ} \mathrm{C}\right)$ for the first 6 hours had no ameliorative effect upon the edema measured in the cortex 46 hours after reperfusion. The mean $( \pm$ SD) percentage water $\left(\mathrm{ml}^{-1} \mathrm{~g}^{-1} \mathrm{x} 100\right)$ for the normothermic group was $86.1 \pm$ $0.7 \%$ for the post-ischemic right cortex and $79.8 \pm 0.7 \%$ for the contralateral left cortex, versus $85.7 \pm 1.4 \%$ (right) and $79.6 \pm$ $0.3 \%$ (left) for that of the hypothermic group.

\section{Experiment 4}

Despite the failure of moderate post-ischemic hypothermia to reduce the accumulation of edema in hypothermia $\left(28^{\circ} \mathrm{C}-29^{\circ} \mathrm{C}\right)$ for the first 6 hours of the 46 hour reperfusion period, this resulted in a mean cortical infarct volume of $122 \pm 57 \mathrm{~mm}^{3}(\mathrm{n}=6)$ (Figure 2 ), which was significantly lower than that of the normothermic control group $\left(175 \pm 22 \mathrm{~mm}^{3}, \mathrm{n}=6\right)(\mathrm{p}<0.05)$ (Table 4). (Table 4). Animals receiving 6 hours of mild hypothermic reperfusion $\left(32^{\circ} \mathrm{C}-33^{\circ} \mathrm{C}\right)$ had a total infarct volume of $149 \pm 39 \mathrm{~mm}^{3}(\mathrm{n}=6)$ at 46 hours, which was less than that of the control group, but not significantly so. The reduction in the size of injury relates to smaller volumes of infarction rather than differences in the amount of swelling or edema, confirming Experiment 3.

\section{Discussion}

In these transient ischemic experiments, the widest BBB openings and increases in $\mathrm{K}_{\mathrm{i}}$ were seen in the post-ischemic right cerebral cortex, which was dissected to include both the core and edge of the region perfused by the MCA. The opening was clearly biphasic, characterized by an initial 10-fold augmentation in $\mathrm{K}_{\mathrm{i}}$ during the first half hour of reperfusion, followed by partial closing, and then a delayed, but progressive, opening between 22 and 46 hours post-reperfusion. Moderate hypothermia during ischemia dramatically reduced infarction and edema, as well as preventing BBB opening, but also had partial effects on infarct size when instituted during the post-ischemic period following normothermic ischemia. ${ }^{11}$ In these studies, we have demonstrated that postischemic moderate hypothermia affects not only the size of the infarct, it does so in tandem with reductions in the opening of the $\mathrm{BBB}$, not by simply reducing the amount of vasogenic edema, but possibly by interfering with the post-ischemic inflammatory response.

This profile of BBB injury shows similarities to findings based on the assessment of Evan's Blue dye extravasation in the cat. ${ }^{13}$ Following one hour of temporary MCA occlusion, dye injected i.v. early in reperfusion caused staining of brain parenchyma. This was followed by a refractory period, and then a delayed opening, which was visible in cats sacrificed five hours or three days post-stroke. The initial acute opening has been described as a 'hemodynamic' BBB opening. ${ }^{4,13}$ Because of acidosis, loss of autoregulation, and vasodilation of the cerebral vasculature, reperfusion results in excessive blood flow or 'luxury perfusion'. High intraluminal blood pressure in the cerebral microvasculature has been shown to induce abnormal pinocytotic transport across endothelial cells, and opening of interendothelial tight junctions. ${ }^{14,15}$ A significant role of arterial pressure in the degree of post-reperfusion opening after

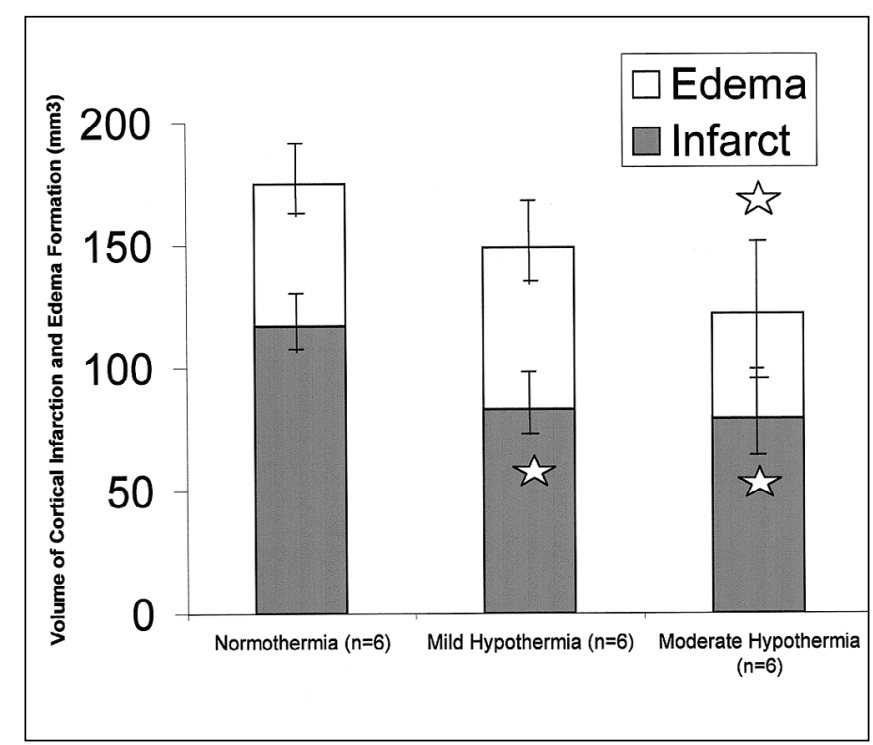

Figure 2: Volume of neocortical infarction for each rat following 2 hours of normothermic transient MCA occlusion and 46 hours of reperfusion, in the first 6 hours of which animals were maintained at either $37^{\circ} \mathrm{C}-38^{\circ} \mathrm{C}$ (normothermia), $32^{\circ} \mathrm{C}-33^{\circ} \mathrm{C}$ (mild hypothermia), or $28^{\circ} \mathrm{C}-29^{\circ} \mathrm{C}$ (moderate hypothermia). The mean edema and infarct sizes are displayed $\pm S D$ (the asterisk denotes significantly less injury $(p<0.05)$. The $n$ value for each group is indicated in brackets. 
Table 4 : Effects of infarct volume and edema formation following post-ischemic hypothermia in MCA Model (Experiment 4)

\section{Variability \\ Group (n)}

Normothermia (6)

Mild Hypothermia (6)

Moderate Hypothermia (6)

\section{Edema \\ $\left(\mathrm{mm}^{3}\right)($ Mean \pm SD $)$}

$58 \pm 17$

$67 \pm 23$

$43 \pm 26$
Infarction

$\left(\mathrm{mm}^{3}\right)($ Mean $\pm \mathrm{SD})$

$117 \pm 13$

$83 \pm 31^{*}$

$79 \pm 33^{*}$
Total Infarct Volume $\left(\mathrm{mm}^{3}\right)($ Mean \pm SD)

$175 \pm 23$

$149 \pm 39$

$122 \pm 57$

$* \mathrm{p}<0.05$, between treatments for ANOVA test.

MCAO has been demonstrated. ${ }^{16}$ After 3 hours of MCAO and 30 min re-circulation, BBB opening to Evan's Blue dye was greatly augmented in rats that had been rendered hypertensive with phenylephrine during the reperfusion period. The magnitude of acute hyperemic BBB opening, and of modulating factors, such as blood pressure, would appear to be an important consideration in utilizing and interpreting the MCAO model. For example, factors such as hypertension, which augment post-reperfusion opening, and the ensuing homeostatic changes might thereby indirectly influence subsequent neuropathological events. On the other hand, one might anticipate that the degree of early post-ischemic BBB opening could have a positive impact on the efficacy of experimental drugs when the chemical nature of these compounds limits their ability to cross the normal BBB. For instance, with the competitive AMPA antagonist NBQX, which penetrates the bloodbrain barrier, effective concentrations of the drug are achieved following transient focal ischemia, perhaps as a consequence of the opening of the barrier at the time the drug is circulating. ${ }^{17}$

In this study, partial recovery from the acute opening of the $\mathrm{BBB}$ was evidenced by the fact that $\mathrm{K}_{\mathrm{i}}$ values at one or four hours post-reperfusion were significantly lower than those measured acutely, but were higher than baseline values, or values for contralateral non-ischemic cortex. The second part of the biphasic opening was then indicated by the significant elevation of $\mathrm{K}_{\mathrm{i}}$ at 22 hours post-reperfusion as compared to that at four hours, with an even more dramatic upward increment taking place between 22 and 46 hours. Accounting for this time delay would seem important in any proposal on the cause(s) of BBB opening, which presumably differs from that underlying the acute post-ischemic opening. In fact, the delayed BBB opening to ${ }^{3} \mathrm{H}$-sucrose is consistent with the published observations that between 24 and 48 hours after transient MCAO, there occurs a rapid evolution of delayed edema, which peaks within this time period, and that infiltration of polymorphonuclear cells follows a similar time course. ${ }^{18}$ Vascular endothelial leakiness was proposed to result from the release of lipid inflammatory mediators through the interaction of injured tissue with infiltrating leukocytes and aggregating platelets. ${ }^{19}$ Among the possible mediators of $\mathrm{BBB}$ dysfunction and formation of vasogenic edema, proteases, bradykinin, histamine, and eicosanoid products of arachidonic acid metabolism and free radicals have been strongly implicated. ${ }^{20}$

It is well documented that neuronal injury is reduced by induction of hypothermia during ischemia, or even by its induction during the post-ischemic reperfusion period. ${ }^{21}$ The experiments in the present study quantitate for the first time a protective effect of post-ischemic hypothermia on the delayed BBB injury that follows temporary MCAO. Mean $\mathrm{K}_{\mathrm{i}}$ values after 46 hours of reperfusion were more than $50 \%$ lower in rats that underwent cooling to $29^{\circ} \mathrm{C}$ for 6 hours. Although a light degree of halothane anesthesia in the cooled rats may have contributed a protective effect, efficacy of lowered brain temperature per se was suggested by the fact that $28^{\circ} \mathrm{C}-29^{\circ} \mathrm{C}$ was more protective than $32^{\circ} \mathrm{C}-33^{\circ} \mathrm{C}$. Separate experiments showed, however, that the 6 hours of hypothermic treatment at $28^{\circ} \mathrm{C}-29^{\circ} \mathrm{C}$ did not reduce the amount of edema present at 46 hours post-reperfusion, even though this treatment appeared to favourably affect both BBB damage and infarct volume.

Post-ischemic hypothermic protective mechanisms may be related to a slight attenuation in the reperfusion hyperemia. During reperfusion, hypothermia may reduce leukotrienes, ${ }^{22}$ improve glucose utilization and blood flow, ${ }^{23}$ and slow free radical reactions and the propagation of lipid peroxidation cascades. This could prevent the leakage of proteins and the accumulation of extracellular fluid ${ }^{24}$ and inhibit the biosynthesis, release and uptake of neurotransmitters, such as glutamate and dopamine. ${ }^{25}$ There are two massive glutamate release points in the first 4 hour period of reperfusion following MCA/CCA occlusion. ${ }^{26}$ The quantal release of glutamate has been recently correlated with the size of neocortical infarction in focal ischemia ${ }^{27}$ and may result in endothelial cell damage in the BBB. The blockade on the non-NMDA glutamate receptors attenuates brain damage. ${ }^{17}$ Therefore, any reduction of glutamate concentration in the extracellular space by delayed hypothermia may protect against brain damage.

In conclusion, following transient focal ischemia, measurements of $\mathrm{K}_{\mathrm{i}}$ for $\mathrm{BBB}$ permeation of ${ }^{3} \mathrm{H}$-sucrose have demonstrated both an acute opening, likely hemodynamic in nature, and a delayed opening of the ipsilateral cortex MCAO. Clearly, hypothermia has potent effects on BBB opening ${ }^{28}$ and does reduce infarct size, but through mechanisms other than reducing edema. The quantitative power of $\mathrm{K}_{\mathrm{i}}$ measurements should facilitate the exploration of drug or other treatments to offset the disadvantages of reperfusion therapy (BBB opening and edema) and facilitate its benefits. The understanding of the interplay between microvascular damage, edema, inflammation, and neuronal death hours after thromboembolic stroke is critical to the development of successful stroke therapies. 


\section{ACKNOWLEDGEMENTS:}

Supported, in part, by grants from the Heart and Stroke Foundation of Canada. Alastair Buchan is a Senior Scholar of the Alberta Heritage Medical Research Foundation.

\section{REFERENCES}

1. Rapoport SI. Sites and function of the blood-brain barrier. In: Rapoport SI, ed. Blood-Brain Barrier in Physiology and Medicine. New York: Raven Press, 1976: 43-86.

2. Betz AL. Oxygen free radicals and the brain microvasculature. In: Pardridge WM, ed. The Blood-Brain Barrier. Cellular and Molecular Biology. New York: Raven Press, 1993: 303-321.

3. Betz AL, Keep RF, Beer ME, Ren X-d. Blood-brain barrier permeability and brain content of sodium, potassium and chloride during focal ischemia. J Cereb Blood Flow Metab 1994; 14: 2937.

4. Klatzo I. Concept of ischemic injury associated with brain edema. In: Inaba Y, Klatzo I, Spatz M, eds. Brain Edema. Tokyo: Springer, 1984: 1-5.

5. Brint S, Jacewicz M, Kiessling M, Tanabe J, Pulsinelli W. Focal brain ischemia in the rat: methods for reproducible neocortical infarction using tandem occlusion of the distal middle cerebral and ipsilateral common carotid arteries. J Cereb Blood Flow Metab 1988; 8: 474-485.

6. Buchan AM, Xue D, Slivka A. A new model of temporary focal neocortical ischemia in the rat. Stroke 1992; 23: 273-279.

7. Kaplan B, Brint S, Tanabe J, Jacewicz M, Wang X-J, Pulsinelli W. Temporal thresholds for neocortical infarction in rats subjected to reversible focal cerebral ischemia. Stroke 1991; 22: 1032-1039.

8. Preston E, Allen M, Haas N. A modified method for measurement of radiotracer permeation across the rat blood-brain barrier: the problem of correcting brain uptake for intravascular tracer. J Neurosci Meth 1983; 9:45-55.

9. Ohno K, Pettigrew KD, Rapoport SI. Lower limits of cerebrovascular permeability to nonelectrocytes in the conscious rat. Am J Physiol 1978; 235: H299-H307.

10. Preston E, Haas N. Defining the lower limits of blood-brain barrier permeability: factors affecting the magnitude and interpretation of permeability-area products. J Neurosci Res 1986; 6: 709-716.

11. Xue D, Huang ZG, Smith KE, Buchan AM. Immediate or delayed mild hypothermia prevents focal cerebral infarction. Brain Res 1992; 587: 66-72.

12. Ishimaru S, Hossman KA. Relationship between cerebral blood flow and blood-brain barrier permeability of sodium and albumin in cerebral infarcts of rats. Acta Neurochir 1990; 51(S): 216-219.

13. Kuroiwa T, Ting P, Klatzo I. The biphasic opening of the bloodbrain barrier to proteins following temporary middle cerebral artery occlusion. Acta Neuropathol 1985; 68: 122-129.
14. Westergaard E, van Deurs B, Brondsted HE. Increased vesicular transfer of horseradish peroxidase across cerebral endothelium, evoked by acute hypertension. Acta Neuropathol 1977; 37: 141-152.

15. Nagy Z, Mathieson G, Huttner I. Blood-brain barrier opening to horseradish peroxidase in acute arterial hypertension. Acta Neuropathol 1979; 48: 45-53.

16. Cole DJ, Matsumura JS, Drummond JC, Schultz RL, Wong MH. Time- and pressure-dependent changes in blood-brain barrier permeability after temporary middle cerebral artery occlusion in rats. Acta Neuropathol 1991; 82: 266-273.

17. Buchan AM, Xue D, Huang ZG, Smith KE, Lesiuk H. Delayed AMPA receptor blockade reduces cerebral infarction induced by focal ischemia. NeuroReport 1991; 2: 473-476.

18. Hsu CY, Liu TH, Xu J, et al. Arachodonic acid and its metabolites in cerebral ischemia. Ann NY Acad Sci 1989; 559: 282-295.

19. Hsu CY, Liu TH, Xu J, Hogan EL, Chao J. Lipid inflammatory mediators in ischemic brain edema and injury. In: Bazan NG ed. Lipid Inflammatory Mediators in Ischemic Brain Damage and Experimental Epilepsy. New Trends Lipid Mediators Research. Basel: Karger, 1990: 85-112.

20. Wahl M, Unterberg A, Baethmann A, Schilling L. Mediators of blood-brain barrier dysfunction and formation of vasogenic brain edema. J Cereb Blood Flow Metab 1988; 8: 621-634.

21. Ginsberg MD, Sternau LL, Globus MYT, Dietrich WD, Busto R. Therapeutic modulation of brain temperature: relevance to ischemic brain injury. Cerebrovasc Brain Metab Rev 1992; 4: 189-225.

22. Dempsey RJ, Combs DJ, Edwards MM. Moderate hypothermia reduces post-ischemic edema development and leukotriene production. Surgery 1987; 21: 177-181.

23. Busto R, Dietrich WD, Globus MY, Ginsberg MD. Postischemic hypothermia inhibits CA1 hippocampal ischemic neuronal injury. Neurosci Lett 1989a; 101: 299-304.

24. Dietrich WD, Halley M, Valdes I, Busto R. Interrelationship between increased vascular permeability and acute neuronal damage following temperature controlled brain ischemia in rats. Acta Neuropathol 1991; 81: 615-625.

25. Busto R, Globus MYT, Dietrich WD, et al. Effects of mild hypothermia on ischemia-induced release of neurotransmitter and free fatty acids in rat brain. Stroke 1989b; 20: 904-910.

26. Osuga H, Hakim AM. The changes in extracellular glutamate concentration during focal ischemia in rat. Can J Neurol Sci 1992; 19: 301-302.

27. Butcher SP, Bullock R, Graham DI, McCulloch J. Correlation between amino acid release and neuropathologic outcome in rat brain following middle cerebral artery occlusion. Stroke 1990; 21: 1727-1733.

28. Preston E, Sutherland G, Finsten A. Three openings of the bloodbrain barrier produced by forebrain ischemia in the rat. Neurosci Lett 1992; 149: 75-78. 